\title{
VALUES IN THE ACTIVITIES OF VOLUNTEER FIRE BRIGADES. A COLLECTIVE CASE STUDY
}

\author{
Sylwia Wrona* (i) http://orcid.org/0000-0003-1881-0370
}

\begin{abstract}
Background. Volunteer fire brigades are primarily active at the local level; they are an organizational form of a self-organizing community; they build and benefit from social capital and pursue many social objectives. The local community - the main audience of their activities - often clusters around them. The activities of volunteer fire brigades result from legal obligations, but also from the values shared by the firefighting community.
\end{abstract}

Research aims. The research objective was to identify values shaping the organizational communities of firefighters and activities determined by such values. The values adhered to by volunteer fire brigade members as well as their activities for the benefit of local communities were identified, including those dedicated to sustaining the volunteer fire brigades' existence.

Methodology. The strategy for organizing data acquisition and presentation was a collective case study. The research methods that served the purpose of the research included individual interviews, group interviews, participant observations, and analysis of existing documents.

Findings. The values that shape firefighting communities comprise a sense of public service, trust, friendship, kindness, loyalty, solidarity, respect and cooperation. By treating their commitment as service, firefighters fulfil the need of a sense of community, which they extend beyond organizational boundaries by dedicating their actions to local communities.

Keywords: activities, values, volunteer fire brigades.

JEL Codes: L31.

* Jagiellonian University in Kraków. E-mail: sylwia.wrona@uj.edu.pl. 


\section{INTRODUCTION}

The essential condition for the establishment and development of non-governmental organizations is the social activity of citizens, which is understood as their participation in "organized forms through the joint determination of objectives, principles, methods and forms of activity, the development of conditions and participation in activities" (Hrynkiewicz, 2002). At the local level, NGOs use their organizational capacities and participate in the formation of local communities, improving the quality of citizens' life, as well as taking responsibility for local development, attachment to democratic values and practices (Anheier, 2005; Lundåsen, 2014). In particular, local NGOs bring together the needs of individuals and larger groups, increase the sense of community and identity, and build inter-organizational and interpersonal ties (Bogacz-Wojtanowska, 2013).

One of the forms of non-governmental organizations is volunteer fire brigades (VFBs), which are associations that perform primarily rescue, property protection and fire-fighting functions. What distinguishes them is their specific legal and financial position, the social dimension of the activity of members of volunteer fire brigades and their cooperation with many other organizations (Wrona, 2017).

Volunteer fire brigades operate in a specific space, and their location, community awareness, local activities and history make them rooted in the local community. In publications focusing on the social activities of specific localities, the activities and persistence of voluntary fire brigades serve as an example to emphasize their historicity, tradition and social activity (Tomczak, n.d.; Wesołowski, n.d.). The importance of the community of voluntary fire brigade members is reflected in their cultural identity, shared common values and symbols, group roles, as well as significant part in social relationships. Voluntary fire brigades are an example of initiating, planning and implementing activities for the benefit of the local territory and community, as well as the general public (Simpson, 1996). As local organizations, they reinforce local identity, co-create values and impart skills to cope with natural disasters (Simpson, 1996).

The volunteer fire brigades often serve as an example of the most active organizations in rural areas, important for the development of villages, creating cultural community practice and self-organization, 
without which local communities cannot imagine their local social life (Goszczyński, Knieć \& Czachowski, 2015; Rakowski, 2016).

Publications focusing on the activities of VFBs present the history and functioning of particular units (Karaś \& Szafran, 2011; Stachowiak, 2011); the character of voluntary service and volunteers (Carpenter \& Myers, 2010; Alkema, Murray \& McDonald, 2013); leadership (Smeby, 2014); fire protection planning, strategy and policy (Srekl, 2014); recruitment and education of firefighters (Srekl, 2014); location and number of existing VFBs, including their impact on the effectiveness of their natural actions (Church \& Wenwen, 2016; Pérez, Maldonado \& Marianov, 2016); and promotion and protection of their physical and mental health (Sattler, Boyd \& Kirsch, 2014; Wagner \& Waters, 2014). However, what is missing is a reflection on actions ensuing from the values and attitudes declared and manifested by VFB members.

Thus, the objective of the research was to identify the values shaping the organizational communities of volunteer firefighters and determining their activities. In order to achieve the objective, the author decided to apply the research strategy of a collective case study purposefully selected to describe the values recognized by VFB members and their activities for the benefit of local communities, with particular emphasis on the role of these values in the persistence of volunteer fire brigades.

\section{THE ROLE AND ACTIVITIES OF VOLUNTARY FIRE BRIGADES IN POLISH LOCAL COMMUNITIES IN THE LITERATURE ON THE SUBJECT}

Organizations such as volunteer fire brigades, rural housewives' associations, village community centres and local schools are places where social activities are undertaken. They are associated with historical events important for an entire village and the development of its infrastructure built within the framework of inhabitants' voluntary community work (Rakowski, 2016). The very notion of voluntary community work was popularized during the communist era in Poland and is associated with the people's enthusiasm towards and pride in activities undertaken as part of it, which is evidence of local communities' resistance to politics (Rakowski, 2016). 
As participants in local communities' life, VFBs can reinforce and develop various economic resources, make people more sensitive to democratic values, and encourage their active participation in public life (Bednarek-Szczepańska, 2011). The life of local communities in rural and rural-urban areas is often centred around VFBs. Voluntary fire brigades are also involved in local communities' cultural practices, for instance, the organization of various periodic events and meetings. Their role in the local community is an important bonding element providing a sense of social identity or solidarity (Haddad, 2004; Haski-Leventhal \& McLeigh, 2009). Firefighters with their attributes such as uniforms, badges and paramilitary style command respect and recognition as entities of social control, while lacking the coercive and punitive aspects associated with the police.

Due to the activity of citizens, mainly in rural areas and small towns, there are 16,000 voluntary fire brigades with 690,000 members in Poland. The average VFB has 37 members (Adamiak, Biejat \& Charycka, 2016). Importantly, $61 \%$ of the surveyed firefighters claim that they maintain frequent contacts with the local community and local residents (Adamiak, 2013). The recipients of VFBs' activities include mainly residents of the immediate area, children and adolescents, as well as the elderly. The dominant participants of VFBs' cultural activities are both their members and people not associated with the organization (Adamiak, Biejat \& Charycka, 2016).

The most important areas of their activity are rescue, security and defence services (Adamiak, Biejat \& Charycka, 2016). Other areas include education and upbringing, sports, tourism, recreation and hobbies, environmental protection and ecology, culture and art, religion, social services, social assistance, support for NGOs and civic initiatives, health care and local development (Adamiak, Biejat \& Charycka, 2016). The areas of activities undertaken by VFBs influence their image in local communities. Local communities associate VFBs with rescue and protection activities that make them feel safer.

What is also highlighted is the civic, social and formal dimensions of the activity of VFBs (FIO, 2016). The civic dimension is proved by their mission, identity and organizational culture resulting from cultivation of traditions and history as well as their firm position in local communities, the support of members and volunteers, and democratic governance. The social dimension is considered in terms of acting for the common good, the local community and its individual members, 
with the local community being the main recipient of VFBs' activities and their most important partner. Finally, the formal dimension is equated with the provisions of the law, fulfilment of duties, observance of rules, as well as the structure, i.e. the general meeting of members, the management board, the audit committee and other appointed bodies.

Despite their formal status of an association, volunteer fire brigades, due to the objective of their activity, i.e. fire protection and rescue operations, are often not classified as NGOs, which is a mistake (Golba, 2012). Presenting a cultural offer for the local community, their members are guided by concern for the environment and local history, traditions and culture, the need to expand the area of activities, promote the region, continue the mission or raise additional funds (Adamiak, Biejat \& Charycka, 2016). Undertaking additional activities by volunteer firefighters requires their commitment to intergroup relations (a sense of community) and to organizational goals (Lee \& Olshfski, 2002).

The sense of community of members of voluntary fire brigades is visible in their cultural identity and possible due to the sharing of common values and symbols, fulfilling group roles and playing a significant part in social relationships. What distinguishes volunteer fire brigades from other third sector organizations is precisely the declarations concerning their professed values. Among their most important values, firefighters mention effectiveness, trust, honesty, concern for the common good and faithfulness to traditions. However, attachment to traditions is the least frequent answer given by the other participants of the survey (Herbst, 2008). The members of voluntary fire brigades also claim that discipline, solidarity with others and the use of the best practices are the most important for them (Herbst, 2008). According to Ewa Bogacz-Wojtanowska (2006, p. 53), "from the late $18^{\text {th }}$ through the $19^{\text {th }}$ century (especially during the positivist period), social organizations played a special role in sustaining the national spirit and preserving Polish culture and traditions."

\section{METHODOLOGY}

The undertaken research problem focuses on the values and activities of members of voluntary fire brigades. By identifying VFBs as organizations firmly rooted in local communities (Adamiak, Biejat \& 
Charycka, 2016), the author focused particularly on the exploration of the role played by VFBs in local communities. Hence, the following research questions were posed:

1. What are the values shaping the firefighting community?

2. What actions are undertaken by volunteer fire brigades as a result of their professed values?

3. How do the activities and values of VFB members influence the sustainability of voluntary fire brigades and their rootedness in local communities?

The author adopted the interpretative-symbolic paradigm, according to which the most important task of the researcher is to understand and present meaning from the perspective of an engaged observer or member of an organization. The resulting concepts are subjective, but they show the importance of interpretations of reality by organization members (Sułkowski, 2012).

In order to achieve the formulated objective, the author decided to follow the strategy of a collective case study, understanding it as the organization of the process of data collection and presentation (Stake, 2005). This choice resulted from the need to obtain a variety of data on the activities of VFBs, as the knowledge of a diversity of cases allows the researcher to better understand the problem/case (Stake, 2005). As part of the collective case study, the author conducted a qualitative study in four selected volunteer fire brigades. These organizations were selected according to the following criteria: their location (four provinces: Dolnoślaskie, Małopolskie, Świętokrzyskie, Łódzkie), the local range of activities, the length of operation.

The research was conducted from February 2018 to April 2019. The research methods used to achieve the objective included 6 in-depth individual interviews, 2 group interviews, participant observations and analysis of the existing documents. The participants' statements from individual and group interviews were anonymized for the purpose of presenting research results. The author decided to conceal the identity of the respondents by assigning a capital letter and a number to each quote. The letter denotes the organization of which the interviewee is a member, while the number denotes the member of that organization taking part in the study - according to the order of interviews or the order of speaking in a group interview of members of a particular organization. An attempt to combine different perspectives and a variety 
of results is called triangulation (Silverman, 2005); it was intended to increase the reliability of the obtained results (Flick, 2007).

The author analysed and interpreted the data by repeatedly reading and comparing the acquired research material, both during and after the research. The resulting in-vivo codes were thematically categorized.

\section{THE VALUES AND ACTIVITIES OF VOLUNTARY FIRE BRIGADES - RESEARCH RESULTS}

One of the most important values that shape communities of firefighters is the sense of public service shared by them. When talking about their involvement in fire brigades' activities, members of voluntary fire brigades emphasize most of all the fact that they regard it as "service." At the same time, they distance themselves from the word "work," which they associate strictly with formal employment. This is important for them because being on duty and not at work, they know what they can expect and demand from each other:

Being a firefighter is not a job, to begin with. It is a completely different dimension. Everyone goes to work to do their job, and this is just a hobby, a passion, an interest, something more. (C1)

As I say, it's not just a job, it's service, so for me it's also a bit of a sacrifice, because no money can pay for it, it's unpredictable and, let's say, incalculable, if we were to express it in pecuniary categories, that this much is due... (A1)

Accepting the role of volunteer firefighters, brigade members declare their readiness to assume all related responsibilities, above all those concerning the rescue, protection and firefighting (safety) functions. Due to these types of responsibilities, among other things, the interviewees claim that volunteer firefighters are characterized by self-discipline, self-control, diligence, conscientiousness, beneficence, generosity and loyalty. These values combine an attitude of willingness to perform public service with taking responsibility for one's role in the firefighting community and the local community, and the firefighter ethos:

Surely, there must be dedication, determination, enormous self-discipline; courage, that's a fact, because we go where others run away from. I mean, you also have to be afraid, because it's not about not being afraid, because only a fool is not afraid, but you need this 
courage. What else? Goodness. A man has to be good to help people, that's really it. (A2)

When you take on such a role, you have a responsibility, you cannot give it up overnight, because there are a lot of things that have to run their course, and now, because I don't want to, I'm going to give it up... There is no such thing. Such people are not suitable for this, because, as I say, there are certain things which have to be completed. (A1)

They believe that if they were not involved in volunteer fire brigade activities, they would fulfil their need to be involved in the community life in other circumstances, because they perceive themselves as people who need to be socially active. Their way to contribute to the community is to get involved in social activation measures. They also associate social activation with the concept of "social work" or "voluntary community work":

I've always wanted to do voluntary community work, to help people, and to what extent, well, it just sort of happened. (A2)

Because there are initiatives, in the past it was voluntary community work, but today there are initiatives where, for example, the commune leader has a community-related idea and the firefighters help him. (D1)

The history of establishing a fire brigade in a given locality is connected with the efforts of its inhabitants and future firefighters to build a fire station and develop the surrounding area. Volunteer firefighters are responsible or jointly responsible for the construction or modernization of many facilities located in the area where a particular VFB operates. According to the respondents, the objective of their activity is a broadly understood provision of assistance to the local community. Thus, it is another value and individual characteristic of volunteer firefighters:

We help each other in times of need. And also other residents. We have a boy here who is ill, and we've also organized a charity ball. (C3)

If, for example, we do something here for our community. This fire station, this other part, I'll show you in a moment, the firemen built it themselves, they brought their tools, we only got the materials from the commune office, they bought the material for us, and they built it themselves. They came on Saturdays. (A1) 
Again, this value coexists with the notion of service, but also with the notions of sacrifice, a sense of vocation, mission, selflessness, love for and assistance to others. Above all, help offered to others is linked to the values of love and sensitivity, which, in a sense, condition one another:

You have to be good to be able to offer such help, to be able to reach out to the injured person, or something. So, you really have to have some love for your fellow human beings. Because, as I said, it's not just a job, it's service, so it's a bit of a sacrifice, as far as I'm concerned, because no money can pay for it, it's unpredictable and, let's say, incalculable, if we were to express it in pecuniary categories, that this much is due. So here, I think, the man himself, his conscience, a little refinement, gentleness... I don't know, but love for your fellow human being is probably the most important thing. You have to love these people in order to be able to help them. (A3)

But somewhere there is a calling and a desire to do it, because it's all done for free and you don't get anything out of it, no money. (B2)

It is worth noting that, for many of the respondents, being a firefighter is a value in itself, as many of them claim that "one is born a firefighter." In this context, this value is indispensable, included in the identity of the firefighter, being a part of his life. Being born a fireman is for them equivalent to having a passion for firefighting. They also note that if someone "does not feel they are a fireman," they cannot acquire it. At the first sign of trouble, they give up on further involvement in VFB activities:

I don't know, I was just born that way I guess, and it was so. (A1)

Another value professed by voluntary firefighters, i.e. maintaining and cultivating traditions, particularly family traditions, stems from the passion for firefighting and the belief that it is inherited from ancestors. In a way, traditionalism itself, which will be discussed later, shapes the manner and type of activities undertaken by firefighters. The analysed cases indicate that community awareness constitutes an important element in the history of a given family. Performing and combining various social and political functions are for them a natural continuation of what their ancestors did, although in different systemic circumstances: 
Fire-fighting is most often inherited, I call it the fire-fighting craze, it is inherited from your grandfather, from your father. This is something that, well, I have in my blood, because both my grandfather, which is documented, and my father, who will be at the meeting today, are people who always were in the fire brigade and never gave it up, despite the fact that the winds of history would blow in different directions. (D2)

Well, I've been in this fire brigade, I say, well, for three generations, so I say, starting from my grandfather, so I started from childhood. (B1)

It is not only active firefighters that are involved in their brigades' activities, but also their families, who support them by co-participating in entertainment, cultural and religious events. The respondents emphasize that the firefighter's dedication is supported by the dedication of his family, who sacrifice their free time so that the firefighter can participate in rescue operations and is always ready for it (has the required equipment):

I would say that the firefighting community is not only made up of firefighters, but their whole families. It is the whole family, because for a volunteer to be that volunteer, the whole family has to work for it. The wife has to substitute for him when the firefighter is not there, and also has to support him somehow. (A1)

I'll show you later in the chronicles, there were 12 people, and now, this year, it's already 70 . Well, because little kids come. The little ones who were there... It's beautiful in general... Because the fireman always comes with his wife and kids. Usually, the wife is also in the fire brigade, but the children will definitely be in the fire brigade. (A2)

Volunteer firefighters perceive themselves as a community. They believe that what unites them is shared values and attitudes, including voluntary participation, interests, volunteerism and willingness to serve. Firefighters describe themselves as a group of volunteers, working together, driven by an inner need to be able to achieve a common goal:

We are a group of people who pursue a common goal, who have some common intention, a group of individuals who understand each other, who cooperate with each other for sure, and try to fit in. So there has to be unity there, more or less, acceptance of one another in terms of community, understanding. That would be the most important 
things, acceptance, understanding and striving for common goals, because otherwise... (A1)

The trust and faith in the fire brigade community that they believe they form also stem from the conviction shared by the members of the fire brigade concerning the desire to help other people. Thus trust, as another value, is for them the foundation and stimulus for the remaining values that guide them in their actions for and with the members of the volunteer fire brigade and the local community. The firefighting community consists of not only enrolled and active members and their families, but also honorary and supporting members:

And sometimes, they are not our members here, they just come here. For example, to clean the fire station before an event, the windows and so on; I won't tell the children to do that, just the women. Well, we have three active women, but we have some more windows, so the mums come and we clean the windows, then we make coffee and cakes and sit, and improve the brigade. (A2)

The values generated by the sense of community influence, trigger and sustain the need to organize different types of activities for the benefit of both firefighters and local communities. These include: attending weddings and funerals of people important to members of the fire brigade, wearing uniforms representing firefighter values, celebrating holidays not related to the activities of the fire brigade (carnivals, Christmas meetings) or organizing events related to the passions and interests of fire brigade members (hiking, going to the cinema or watching sports events together). Such activities are supposed to foster a better understanding of each other, improve communication, show various benefits of belonging to a firefighting community and develop opportunities to establish long-lasting acquaintances based on mutual sympathy, i.e. the basis for developing the values of friendship and kindness:

Friendship, let me put it this way, friendship, because friendships are born, whole families come here. For example, we have the firefighters' Christmas Eve once a year. When I started, it was difficult, because the older people didn't really want it ... Because a fireman always comes with his wife and children. Usually, the wife is also in the fire brigade, but the children will definitely be in the fire brigade. (A2) 
Work for the benefit of the local community is understood as, among other things, organization of entertainment and cultural events, participation in religious festivals, charitable activities, participation in fire-fighting and rescue operations, activities aimed at maintaining public safety, provision of premises, participation in new investment projects, maintenance of real property, performance of repairs, educational activities, documentation of events important for the town and its inhabitants. Apart from the practical dimension consisting in improving the quality of life of the local community, these activities also have a deeper dimension leading to the development of a sense of belonging to the local community. This is another value of fire brigade members: building and developing bonds and relationships, solidarity, respect and cooperation among members as well as between members and the local community:

-Not only. We cleaned up the car parks around... Before Easter, when there was some snow, blizzards, the boys also cleared the snow and everything.

- Now, for example, this Saturday, they cleaned the cobbled area near the school. It's also on Facebook. Well, this week, yesterday, a series of first aid training for the whole school, all classes, started. (C2 and 4)

When we have an anniversary, we usually have a festival and then everyone who wants to come is invited. Here, in the sports field or at the events hall, we usually have some music, artistic performances, shows, and then everyone who wants to come, all the residents, attend. (A1)

This sense of community between firefighters and the local community enables effective and well-developed cooperation, which is another value attributed to firefighters. Firefighters cooperate during every rescue operation. They also cooperate with other organizations such as the Church, local government units, the Association of Voluntary Fire Brigades, formalized and non-formalized NGOs (rural housewives' associations, local action groups, etc.), uniformed services, schools, sports organizations and other voluntary fire brigades. Thanks to this cooperation, voluntary fire brigades participate together with their local communities in social and cultural events (e.g. harvest festivals, feasts, memorials, commemorative holidays, pilgrimages): 
When a priest needs to do some cleaning work in the area, because the parish council can't always manage, they know that we have these men here, we get together and we go, for example. We've even repaired someone's sewage system somewhere, because we have these pumps, and we helped them, to fix something, for example. (A1)

School, senior citizens, parish choir. What else? Well, the district board, that's normal. We participate in various competitions connected with our fire engine; we promote our village here... (C1)

And we establish cooperation with other brigades. Because the unit also develops with other brigades, exchanging views, experiences, knowledge. (C5)

The activities aimed at the continuation of voluntary fire brigades' existence involve the continuation of fire brigades' traditions, the ritualization of activities, respect for history and its commemoration (chronicles, memorials), remembrance of ancestors, care for the legacy, transmission of passions and responsibilities to the next generations, the strategic planning of the development of activities, and care for the property accumulated by particular brigades. Most of the activities triggered by the both symbolic and factual desire to survive are reflected in the efforts to consolidate and socialize the organization:

And he promoted it a lot, for example I always went there with my kids, with the adolescents, with the team, one or the other, to show them what it was like there, those old nozzles, everything... Just this history, nicely arranged, so... There are people who promote it. These chronicles in general. There's a chronicle in each brigade. (A1)

At the same time an important role is played by organizational leaders, who can effectively encourage new volunteers, especially young people, to join the fire brigade. The future of the fire brigade will largely depend on the commitment of such new members. Therefore, an important element in planning the development of fire brigades is Youth Fire Brigades where young people can gain knowledge and skills necessary to perform rescue, protection and firefighting operations, as well as become familiar with the organizational culture of VFBs:

He has one more thing, he has been a volunteer fireman since he was a child, because of his grandfather and father. He got into firefighting through a family passion, through youth firefighting teams. (D2) 
And this is also a desire to instil something like that in the young ones. Because at the moment there are no scout organizations or anything like that in Poland, at least in rural areas. And this is a lot for them. Because they can also cooperate with each other and want to do something. For them, taking part in competitions, in tournaments, is also a considerable distinction, an opportunity. (C2)

Thus, the history of a locality is often connected with the history of firefighting units in the area. Firefighters have organizational resources that confirm, commemorate and illustrate their social and cultural capital. These resources include numerous photographs, chronicles and documents, and even private museums created by individuals with strong ties to the community who wish to preserve the memory of the past. Such private museums, called memorial chambers, are established in or near the homes of residents, and serve their families, local inhabitants and educational organizations. And in residents' backyards, it is possible to find old and no longer used firefighting and rescue equipment. Its owners or their descendants are happy to tell those interested about the persistence as well as the changing goals and values of volunteer fire brigades:

There are such units . . he's already dead, our Chief Fireman. He was such a keen fireman. He was a chimney sweep, but he has... For example, he has this roofed fire hose in his garden, he has a lot of equipment ... And he promoted it a lot, for example, I always went there with my kids, with the youth, with the team, one or the other, to show them what it was like there, those old nozzles, everything... Just this history, nicely arranged, so... There are people who promote it. These chronicles, in general. There's a chronicle in each unit. (A2)

\section{DISCUSSION AND CONCLUSION}

The values that shape firefighting communities include, among others, a sense of public service, trust, friendship, kindness, loyalty, solidarity, respect and cooperation. Firemen are still guided in their actions by values and virtues expressed in numerous slogans, calls, specially prepared speeches dedicated to the activities of fire brigades and the attitudes of their members (Szyller, 1901a; 1901b; Wójcikiewicz, 1928). These slogans call for unity, cooperation, trust, diligence, dedication, perseverance, courage and responsibility. They are repeated in need of 
initiating common actions and increasing firefighters' commitment to work for the benefit of the organization and the community; they are an element of various ceremonies and an important part of firefighters' traditions and history. They are repeated by successive generations and grow into the fabric of what is understood as fire service. As Małgorzata Boguni-Borowska (2015, p. 7) writes, "the condition and quality of communities are highly dependent on this canon of values and the extent to which such values permeate social life."

Values and activities emanate from a narrow understanding of the community of volunteer firefighters, their teamwork that underpins effective firefighting and rescue operations, and more broadly, the local character and rootedness defined by VFBs in terms of space and symbols through integrative activities such as parades, rituals, ceremonies, charitable activities, fund raising, cooperative willingness and community service (Simpson, 1996). The majority of volunteers in VFBs are attached to their villages and their history, the people and their traditions. This results from the need for intergenerational continuity in the recruitment of new members (Simpson, 1996). These practices prove that firefighters' organizations maintain the cultural and historical continuity of self-organization or the tradition of developing civic values (Rakowski, 2016).

The aim of the activities of volunteer fire brigades is to maintain organizational sustainability, which is also related to firefighters' belief in the firm rootedness of VFBs in their local communities and in the perception of their activities as public service (Adamiak, Biejat \& Charycka, 2016). NGOs' social rootedness consists precisely in acquiring and using local resources, participating in local social networks, where relations with stakeholders based on trust and cooperation are important (Hernik \& Kaźmierczak, 2008; Bogacz-Wojtanowska, 2009; 2013). Some activities of VFBs are oriented towards improving the quality of local community life, developing local infrastructure or cooperating with other local organizations. The consequence of these activities is a positive image of VFBs and the popularization of their activities. In this way, VFB members also fulfil their ambitions resulting from their community awareness and a sense of mission. What is characteristic of VFB members is their axiological motivation to engage in NGO activities. This means that they are motivated precisely by a sense of responsibility, honour, mission and service to local communities, 
pursuing a passion, vocation or a sense of duty in compliance with moral values and accepted principles (Polańska, 2015).

This is all the more important for the effectiveness of the activities carried out by VFBs, as the notion of NGOs accountability is also linked to the need to seek public support, because the pursuit of organizational goals is largely connected with the social legitimacy of organizations (Hatch, 2002; Bogacz-Wojtanowska, 2013).

In many cases, volunteer fire brigades are such centres of local communities where their needs, expectations and opportunities intersect. In order to maintain the manner and purposefulness of their activities, they follow their professed values (Adamiak, Biejat \& Charycka, 2016). Thanks to this, members of volunteer fire brigades can envisage what it means to be a firefighter. They perceive the firefighter ethos as the fulfilment of a social mission and awareness of responsibility for other people or selflessness in actions undertaken to help those in need. Perceived in this way, the firefighter ethos is strongly linked to the ethos ensuing from the awareness of community expressed in the values of selflessness, service and the common good, where pro-social activities are intended to support the communal dimensions of public life (Jaworska-Matys, 2015).

All activities aimed at cultivating the remembrance of firefighters' history and traditions and the ritualization of such activities are to strengthen the existence of the firefighter ethos in the awareness of volunteer firefighters. Thanks to the implementation of this ethos in the organizational reality, it becomes possible to create the capacity for the organizational continuity of VFBs.

\section{REFERENCES}

Adamiak, P. (2013). Ochotnicze Straże Pożarne w Polsce. Raport z badania 2012. Warszawa: Stowarzyszenie Klon/Jawor.

Adamiak, P., Biejat, M. \& Charycka, B. (2016). Ochotnicze Straże Pożarne-lokalne centra kultury. Raport z badań. Warszawa: Stowarzyszenie Klon/Jawor.

Alkema, A., Murray, N. \& McDonald, H. (2013). "You can't be selfish in the country." Motivating, Recruiting and Retaining Volunteer Fire Fighters in Rural Communities in New Zealand. New Zealand Fire Service Commission.

Anheier, H.K. (2005). Nonprofit Organizations. Theory, Management, Policy. New York: Routledge. 
Bednarek-Szczepańska, M. (2011). Organizacje pozarządowe na obszarach pozametropolitarnych na przykładzie wybranych regionów. In: M. Wesołowska (Ed.), Wiejskie obszary peryferyjne - uwarunkowania i czynniki aktywizacji (pp. 217-232). Warszawa: Polskie Towarzystwo Geograficzne: Instytut Geografii i Przestrzennego Zagospodarowania im. Stanisława Leszczyckiego.

Bogacz-Wojtanowska, E. (2006). Zarzqdzanie organizacjami pozarzadowymi na przykładzie stowarzyszeń krakowskich. Kraków: Wydawnictwo Uniwersytetu Jagiellońskiego.

Bogacz-Wojtanowska, E. (2009). Potencjał organizacji pozarządowej i obszary jego analizy. Kwartalnik Trzeci Sektor, 18, 77-86.

Bogacz-Wojtanowska, E. (2013). Zdolności organizacyjne a współdziałanie organizacji pozarzadowych. Kraków: Instytut Spraw Publicznych UJ.

Boguni-Borowska, M. (2015). Fundamenty dobrego społeczeństwa. Wartości. Kraków: Znak.

Carpenter, J. \& Myers, C.K. (2010). Why volunteer? Evidence on the role of altruism, image, and incentives. Journal of Public Economics, 94(11-12), 911-920.

Church, R.L. \& Wenwen, L. (2016). Estimating spatial efficiency using cyber search, GIS, and spatial optimization: A case study of fire service deployment in Los Angeles County. International Journal of Geographical Information Science, 30(3), 535-553.

FIO [Fundusz Inicjatyw Obywatelskich] (2016). Obywatelski Standard Działań dla Ochotniczych Straży Pożarnych z Województwa Małopolskiego. Ministerstwo Pracy i Polityki Społecznej, http://www.efr.org.pl/images/obywatelski_standard_dzialan.pdf/ (Accessed: $12^{\text {th }}$ February 2020).

Flick, U. (2007). Managing Quality in Qualitative Research. London et al.: Sage. Golba, A. (2012). Poakcesyjny Program Wsparcia Obszarów Wiejskich jako czynnik aktywizujący wiejskie organizacje pozarządowe w województwie łódzkim. Mazowsze Studia Regionalne, 11, 133-143.

Goszczyński, W., Knieć, W. \& Czachowski, H. (2015). Lokalne horyzonty zdarzeń. Lokalność $i$ kapitat społeczny w kulturze (nie)ufności na przykładzie wsi kujawsko-pomorskiej. Toruń: Muzeum Etnograficzne w Toruniu.

Haddad, M.A. (2004). Community determinants of volunteer participation: The case of Japan. Nonprofit and Voluntary Sector Quarterly, 33 (Supplement), 8-31.

Haski-Leventhal, D. \& McLeigh, J. (2009). Firefighters volunteering beyond their duty: An essential asset in rural communities. Journal of Rural and Community Development, 4(2), 80-92.

Hatch, M.J. (2013). Organization Theory: Modern, Symbolic, and Postmodern Perspectives. $3^{\text {rd }}$ Edition. Oxford: Oxford University Press. 
Herbst, J. (2008). Inny trzeci sektor. Organizacje pozarządowe na terenach wiejskich. In: M. Halamska (Ed.), Wiejskie organizacje pozarzadowe (33-77). Warszawa: Instytut Rozwoju Wsi i Rolnictwa Polskiej Akademii Nauk.

Hernik, K. \& Kaźmierczak, T. (Eds.) (2008). Społeczność lokalna w działaniu. Kapitat spoteczny, potencjat spoteczny, lokalne governance. Warszawa: Instytut Spraw Publicznych.

Hrynkiewicz, J. (2002). Rola organizacji obywatelskich w polityce społecznej. In: J. Hrynkiewicz (Ed.), Przeciw ubóstwu i bezrobociu: Lokalne inicjatywy obywatelskie (pp. 59-73). Warszawa: Instytut Spraw Publicznych.

Jaworska-Matys, D. (2015). Tożsamościowe dyskursy społecznikostwa. In: G. Chimiak, K. Iwińska (Eds.), Krajobraz społecznościowy - Polska 2014 (pp. 93-113). Warszawa: Collegium Civitas, Stowarzyszenie Centrum Wspierania Aktywności Lokalnej CAL.

Karaś, B. \& Szafran, P. (2011). Historia OSP Kraczewice 1921-2011. Kraczewice.

Lee, S.H. \& Olshfski, D. (2002). An examination of variations in the nature of employee commitment: The case of paid and volunteer firefighters. International Review of Public Administration, 7(1), 29-38.

Lundåsen, S.W. (2014). Democratic values and civic engagement of local voluntary associations. Nonprofit Management \& Leadership, 24(3), 263-283.

Pérez, J., Maldonado, S. \& Marianov, V. (2016). A reconfiguration of fire station and fleet locations for the Santiago Fire Department. International Journal of Production Research, 54(11), 3170-3186. https://doi.org/10.1080/00207543. 2015.1071894/.

Polańska, D.V. (2015). Motywacje osób niezinstytucjonalizowanych sektora społecznościowego. In: G. Chimiak \& K. Iwińska (Eds.), Krajobraz społecznościowy Polska 2014 (pp. 27-47). Warszawa: Collegium Civitas, Stowarzyszenie Centrum Wspierania Aktywności Lokalnej CAL.

Rakowski, T. (2016). Działania edukacyjne w przestrzeniach wsi. Odkrywanie podmiotowości środowisk wiejskich. In: A. Bińka, J. Kościańska, J. Orlikowska \& J. Szymańska (Eds.), Nasze miejsce. Inspirator do pracy z lokalnościa (pp. 99-107). Warszawa: Zespół Stowarzyszenia „Pracownia Etnograficzna” im. Witolda Dynowskiego.

Sattler, D.N., Boyd, B. \& Kirsch, J. (2014). Trauma-exposed firefighters: Relationships among posttraumatic growth, posttraumatic stress, resource availability, coping and critical incident stress debriefing experience. Stress and Health, 30(5), 356-365. https://doi.org/10.1002/smi.2608/.

Silverman, D. (2005). Doing Qualitative Research: A Practical Handbook. London: Sage. 
Simpson, Ch.R. (1996). A fraternity of danger volunteer fire companies and the contradictions of modernization. The American Journal of Economics and Sociology, 55(1), 17-34.

Smeby, L.C., Jr. (2014). Fire and Emergency Services Administration. Management and Leadership Practices. Sudbury (Mass.): Jones \& Bartlett.

Srekl, J. (2014). Computational model of voluntary firefighters. Open Journal of Safety Science and Technology, 4, 42-48.

Stachowiak, B. (2011). Ochotnicze Straże Pożarne Gminy Kawęczyn-zarys historyczny. Kawęczyn: Gmina Kawęczyn.

Stake, R.E. (2005). Qualitative case studies. In: N.K. Denzin, Y.S. Lincoln (Eds.), The Sage Handbook of Qualitative Research (3 ${ }^{\text {rd }}$ Ed.) (pp. 443-466). London et al.: Sage Publications.

Sułkowski, Ł. (2012). Epistemologia i metodologia zarzadzania. Warszawa: Polskie Wydawnictwo Ekonomiczne.

Szyller, L. (1901a). Dziesięcioro przykazań prawego strażaka. Strażak, 1, 4-5.

Szyller, L. (1901b). Dziesięcioro przykazań prawego strażaka. (Dokończenie). Strażak, 2, 2-3.

Tomczak, E. (n.d.). Razem było po drodze. In: A. Theiss (Ed.), Aktywne Społeczności. Zmiana społeczna. Katalog praktyk (pp. 72-75). Warszawa: Stowarzyszenie Centrum Wspierania Aktywności Lokalnej CAL.

Wagner, S.L. \& Waters, C. (2014). An initial investigation of the factor-analytic structure of the impact of event scale-revised with a volunteer firefighter sample. Journal of Loss and Trauma, 568-583.

Wesołowski, R. (n.d.). Zapaleni do działania. In: A. Theiss (Ed.), Aktywne Społeczności. Zmiana społeczna. Katalog praktyk, Vol. 4 (pp. 182-187). Warszawa: Stowarzyszenie Centrum Wspierania Aktywności Lokalnej CAL.

Wójcikiewicz, B. (1928). W jedności silni. Walka z Pożarem: Czasopismo poświęcone sprawom społecznym i obrony przeciwpożarowej zawierajace „Przewodnik Pożarniczy," 2, 1-2.

Wrona, S. (2017). Ochotnicze straże pożarne jako wiejskie organizacje pozarządowe. Studium przypadku Ochotniczej Straży Pożarnej w Bęble. In: E. Bogacz-Wojtanowska \& S. Wrona (Eds.), Nieco inny trzeci sektor - studia przypadków (pp. 17-34). Kraków: Towarzystwo Naukowe Współczesnego Zarządzania. 


\title{
WARTOŚCI W DZIALALNOŚCI OCHOTNICZYCH STRAŻY POŻARNYCH. ZBIOROWE STUDIUM PRZYPADKU
}

\begin{abstract}
Abstrakt
Tło. Ochotnicze straże pożarne działają przede wszystkim na poziomie lokalnym, sa organizacyjna forma samoorganizującego się społeczeństwa, tworzą i korzystaja z kapitału społecznego i realizują wiele celów społecznych. To wokół nich często gromadzi się społeczność lokalna, która też jest głównym odbiorca ich działań. Działalność ochotniczych straży pożarnych wynika z obowiązków prawnych, ale także jest wynikiem podzielanych przez wspólnotę strażacką wartości.
\end{abstract}

Cele badawcze. Celem badań było rozpoznanie wartości kształtujących wspólnoty organizacyjne strażaków i determinowane przez nie działania. Zidentyfikowane zostały wartości wyznawane przez członków OSP i działania OSP na rzecz społeczności lokalnych, w tym te, które zostały dedykowane podtrzymaniu procesu trwania ochotniczych straży pożarnych.

Metodologia. Strategia organizująca pozyskiwanie danych i ich prezentację było zbiorowe studium przypadków. Metodami badawczymi, które posłużyły zrealizowaniu celu badań, były wywiady indywidualne, wywiady grupowe, obserwacje uczestniczace, analiza dokumentów zastanych.

Kluczowe wnioski. Wartościami kształtującymi wspólnoty strażackie są poczucie służby publicznej, zaufanie, przyjaźń, życzliwość, lojalność, solidarność, szacunek i współpraca. Strażacy, traktując swe zaangażowanie jako służbę, realizują potrzebę poczucia wspólnotowości, którą rozszerzają poza granice organizacyjne, dedykując swe działania społeczności lokalnej.

Słowa kluczowe: działania, wartości, ochotnicze straże pożarne. 